Article

\title{
Contemporary and Future Characteristics of Precipitation Indices in the Kentucky River Basin
}

\author{
Somsubhra Chattopadhyay ${ }^{1}$, Dwayne R. Edwards ${ }^{1, *}$ and Yao Yu ${ }^{2}$ \\ 1 Department of Biosystems and Agricultural Engineering, University of Kentucky, Lexington, KY 40546, \\ USA; schattop14@uky.edu \\ 2 Construction Management and Engineering Department, North Dakota State University, Fargo, ND 58108, \\ USA; yao.yu@ndsu.edu \\ * Correspondence: dwayne.edwards@uky.edu; Tel.: +1-859-257-5657 (ext. 123); Fax: +1-859-257-5671
}

Academic Editor: Athanasios Loukas

Received: 31 August 2016; Accepted: 8 February 2017; Published: 10 February 2017

\begin{abstract}
Climatic variability can lead to large-scale alterations in the hydrologic cycle, some of which can be characterized in terms of indices involving precipitation depth, duration and frequency. This study evaluated the spatiotemporal behavior of precipitation indices over the Kentucky River watershed for both the baseline period of 1986-2015 and late-century time frame of 2070-2099. Historical precipitation data were collected from 16 weather stations in the watershed, while future rainfall time-series were obtained from an ensemble of 10 Coupled Model Intercomparison Project Phase 5 (CMIP5) global circulation models under two future emission pathways: Representative Concentration Pathways (RCP) 4.5 and 8.5. Annual trends in seven precipitation indices were analyzed: total precipitation on wet days (PRCPTOT), maximum length (in days) of dry and wet periods (CDD and CWD, respectively), number of days with precipitation depth $\geq 20 \mathrm{~mm}$ (R20mm), maximum five-day precipitation depth (RX5day), simple daily precipitation index (SDII) and standardized precipitation index (SPI, a measure of drought severity). Non-parametric Mann-Kendall test results indicated significant trends for only $\approx 11 \%$ of the station-index combinations, corresponding to generally increasing trends in PRCPTOT, CWD, R20mm and RX5day and negative trends for the others. Projected magnitudes for PRCPTOT, CDD, CWD, RX5day and SPI, indices associated with the macroweather regime, demonstrated general consistency with trends previously identified and indicated modest increases in PRCPTOT and CWD, slight decrease in CDD, mixed results for RX5day, and increased non-drought years in the late century relative to the baseline period. Late-century projections for the remaining indices (SDII, $\mathrm{R} 20 \mathrm{~mm}$ ) demonstrated behavior counter to trends in the trends identified in the baseline period data, suggesting that these indices-which are more closely linked with the weather regime and daily GCM outputs-were relatively less robust.
\end{abstract}

Keywords: climate change; drought; extreme precipitation; Kentucky River Basin

\section{Introduction}

The hydrologic cycle is recognized as subject to significant changes as a result of anthropogenic global warming [1-5]. As per IPCC AR5 estimates, the global average surface temperature will rise by $1.8-4.0^{\circ} \mathrm{C}$ [6]; precipitation is expected to increase by $5 \%-20 \%$ over the period of $1990-2100$, suggesting increasing floods on a widespread basis [7]. Portmann et al. [8] have linked spatial variations in the US temperature trends to variations the in hydrologic cycle with more pronounced effects anticipated in the southern U.S. The authors reported a statistically significant inverse relationship between trends in daily temperature and average daily precipitation across $30-40^{\circ} \mathrm{N}$ latitudes during May-June and a weaker relationship between the variables in the northern $\left(40-50^{\circ} \mathrm{N}\right)$ United States during July-August. 
Karl et al. [9] highlighted a significant increase in extreme precipitation events and moderate to severe droughts for the Southeast U.S. in the 20th century. Sayemuzzaman and Jha [10] investigated spatial and temporal trends in precipitation for North Carolina and found mixed results for annual, Spring and Summer precipitation time series. Up to $100 \mathrm{~mm}$ more total extreme precipitation (95th percentile and greater) is expected in the eastern U.S. by the end of 2050s according to Gao et al. [11]. Chattopadhyay and Edwards [12] studied long-term climatic variability considering the annual trends in precipitation and temperature across the state of Kentucky (84 weather stations) for the time period of 1950-2010. The majority of the stations demonstrated an increasing trend for both precipitation and air-temperature; however, the relatively few statistically significant trends were mostly found along the western parts of the state. Considered collectively, these and similar studies indicate that climate change due to global warming is in progress to varying degrees in North America, at both the regional and smaller (state-wide) scales; the potential for disruptive consequences argues for increased scrutiny of both future changes and likely impacts.

Being less dependent on relatively specific variables such as topography and land use, precipitation is a common subject of investigations into the effects of climate change on the hydrologic cycle. While society is most sensitive to extremes (extreme magnitudes, intensities and frequencies) in precipitation [13], their infrequent nature can raise challenges in accurately assessing them under stationary conditions, let alone non-stationary conditions. For such reasons, precipitation inputs to the hydrologic cycle are often characterized in the form of several statistics and indices, such as numbers of "wet" and "dry" days, number of days with precipitation greater than some threshold depth, and total annual precipitation. Use of such indices is widespread in climate research, with recent applications reported for China by Ren et al. [14], mainland Portugal by Lima et al. [15] and India by Mondal and Majumdar [16].

Historical trends in indices may be identified through simple linear regression or, due to its relative lack of required assumptions, through nonparametric regression $[17,18]$. However, regression can be an unsatisfactory technique for generating projections of climate data due to the lack of physical basis in the predictive model. Rather, the class of complex, physically-based, global-scale models (General Circulation Models (GCMs)) is typically used for this task. Relatively recent research has resulted in enhanced predictive capability through refined representation of the relevant physical processes and more robust coupling of sea, atmosphere and land-based processes [19,20].

Use of GCMs for climate data projections is associated with well-known and substantial challenges. Due to internal model differences, projections can vary significantly with regard to GCMs, output variables, and seasons as discussed by Fu et al. [21]. More relevant to the present study, GCM performance can vary among model outputs. Deser et al. [22] found the internal variability of GCM outputs to be higher for precipitation than temperature, and Rocheta et al. [23] note that precipitation simulations are typically of lower fidelity than others (e.g., temperature). As discussed by Emori et al. [24], additional challenges occur as the result of evaluating outputs, especially precipitation, from climate models on the daily time scale. Lafon et al. [25] have noted that GCMs often simulate daily precipitation to occur more often, but at lower intensities, than observed. Such behavior can introduce bias into daily precipitation statistics and indices. Ines and Hansen [26], for example, reported GCM outputs tended to overestimate runs of dry days even after bias correction for precipitation depths. Mahoney et al. [27] discuss the particular challenges involved in extreme precipitation simulation. Downscaling the relatively course-resolution GCM outputs to regional or local scales is often desirable from the standpoint of decision-making and resource management. While the method of downscaling can have significant impact on the quality of the projections, there remains no consensus on a single best downscaling method (Sunyer et al. [28]). Finally, there is no uniform agreement on how to compare the performance of one model relative to another, with a variety of metrics such as skill scores [29], root mean square error [30] and Nash-Sutcliffe model efficiency [31] in current use. Notwithstanding such challenges, GCM projections remain the state-of-the-art for spatially-consistent assessments of 
future climate and its impacts, with GCM outputs being directly available for application at both large and (through downscaling) relatively local scales.

The objectives of this study were to: (a) evaluate spatio-temporal magnitudes and trends of historical extreme precipitation indices for a river basin in Kentucky; and (b) compare these findings to projections from GCMs. The specific basin to be studied is the Kentucky River basin, a major tributary of the Ohio River that provides water for nearly 70 municipalities and roughly one-sixth of the Commonwealth's population. Given the relatively recent (2008 and 2012) droughts in Kentucky and the Kentucky River basin [32] and the impacts of drought on ecosystems, agriculture and water management, the findings of this study can be beneficial to policy makers, planners and managers entrusted with ensuring appropriate protection and sustained supplies for the basin's residents.

\section{Materials and Methods}

\subsection{Study Area}

The Kentucky River watershed is centered at approximately $38^{\circ} 41^{\prime} \mathrm{N} 85^{\circ} 11^{\prime} \mathrm{W}$ and encompasses an area of roughly $18,000 \mathrm{~km}^{2}$ in the north-central part of the state (Figure 1). Elevations range from $110 \mathrm{~m}$ in the northwest to $998 \mathrm{~m}$ in the southeast with a mean elevation of $554 \mathrm{~m}$. The length of the main stream of the Kentucky River is $418 \mathrm{~km}$. Mean annual rainfall varies from 1107 to $1308 \mathrm{~mm}$, with the southern portion generally receiving more rainfall than the northern. The major land uses in the watershed are forest $(55 \%)$ and hay production $(25 \%)$ with smaller proportions in urban $(8 \%)$, rangeland $(6 \%)$, agricultural $(2 \%)$ and other $(4 \%)$ land uses. The Kentucky River provides $378,000 \mathrm{~m}^{3} /$ day water for drinking and other uses [33].

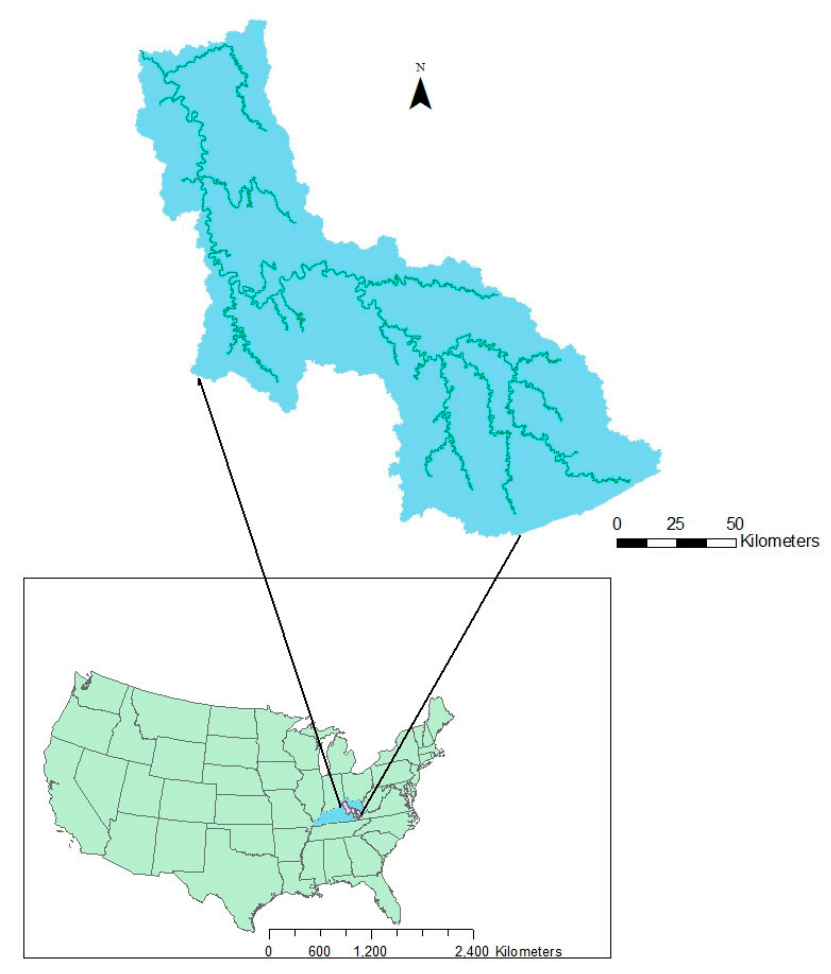

Figure 1. Location of Kentucky River basin inside the United States.

\subsection{Data Collection and Quality Assessment}

Daily precipitation data were obtained from the Global Historical Climatology Network (GHCN) database (http:/ / www.ncdc.noaa.gov/oa/climate/ghcn-daily/) maintained on the National Oceanic and Atmospheric Administration (NOAA) server (https://www.ncdc.noaa.gov/cdo-web/). Sixteen 
weather stations in the watershed were considered for the selected 30-year period of 1986-2015, subsequently referred to as the baseline period. The 30-year record length, which was near the limit of availability for consistent and near-complete stations in the basin, has a greater potential for bias than longer record lengths but is consistent with historical record lengths used in similar analyses [34-36]. Characteristics of the stations are summarized in Table 1, and their locations in relation to elevations, land uses and physiographic regions in the basin are given in Figure 2. The Climatol software package [37] was used to assess relative homogeneity of the data for each station and, had discontinuities been detected, to apply appropriate corrections. No discontinuities were detected in the data, and Climatol was further used to interpolate missing data on the basis of observations at neighboring stations.

Table 1. Weather stations used in the study.

\begin{tabular}{|c|c|c|c|c|c|}
\hline Station Name & Latitude $\left({ }^{\circ} \mathrm{N}\right)$ & Longitude $\left({ }^{\circ} \mathrm{W}\right)$ & Elevation (m) & $\begin{array}{c}\text { Mean Annual Rainfall } \\
(\mathrm{mm})\end{array}$ & Missing Data \\
\hline Whitesburg & 37.1167 & -82.8167 & 355.1 & $1308.0 \pm 184.5$ & $1 \%$ \\
\hline Skyline & 37.0667 & -82.9667 & 366.1 & $1233.0 \pm 197.3$ & $<1 \%$ \\
\hline Carr Fork & 37.2333 & -83.0333 & 309.1 & $1159.9 \pm 226.1$ & $<1 \%$ \\
\hline Hazard & 37.2500 & -83.1833 & 267.9 & $1287.5 \pm 219.1$ & $<1 \%$ \\
\hline Buckhorn & 37.3500 & -83.3833 & 285.3 & $1266.7 \pm 214.7$ & $<1 \%$ \\
\hline Jackson & 37.6000 & -83.3167 & 416.1 & $1273.9 \pm 213.1$ & $<1 \%$ \\
\hline Crab Orchard & 37.4833 & -84.4333 & 335.9 & $1238.0 \pm 199.2$ & $<1 \%$ \\
\hline Berea & 37.5666 & -84.3333 & 309.1 & $1201.0 \pm 192.8$ & $<1 \%$ \\
\hline Danville & 37.6500 & -84.7667 & 291.1 & $1228.4 \pm 247.1$ & $<1 \%$ \\
\hline Dix Dam & 37.8000 & -84.7167 & 265.2 & $1116.4 \pm 251.3$ & $1 \%$ \\
\hline Clay & 37.8666 & -83.9333 & 192.0 & $1172.0 \pm 242.7$ & $<1 \%$ \\
\hline Lexington & 38.0333 & -84.6000 & 294.4 & $1220.6 \pm 227.3$ & $<1 \%$ \\
\hline Frankfort Lock & 38.2333 & -84.8667 & 152.4 & $1176.2 \pm 203.6$ & $2 \%$ \\
\hline Frankfort & 38.1833 & -84.9000 & 230.1 & $1249.0 \pm 250.9$ & $<1 \%$ \\
\hline Georgetown & 38.2000 & -84.5500 & 271.0 & $1224.2 \pm 233.8$ & $<1 \%$ \\
\hline Gest Lock & 38.4167 & -84.8833 & 149.4 & $1153.6 \pm 201.0$ & $1 \%$ \\
\hline
\end{tabular}

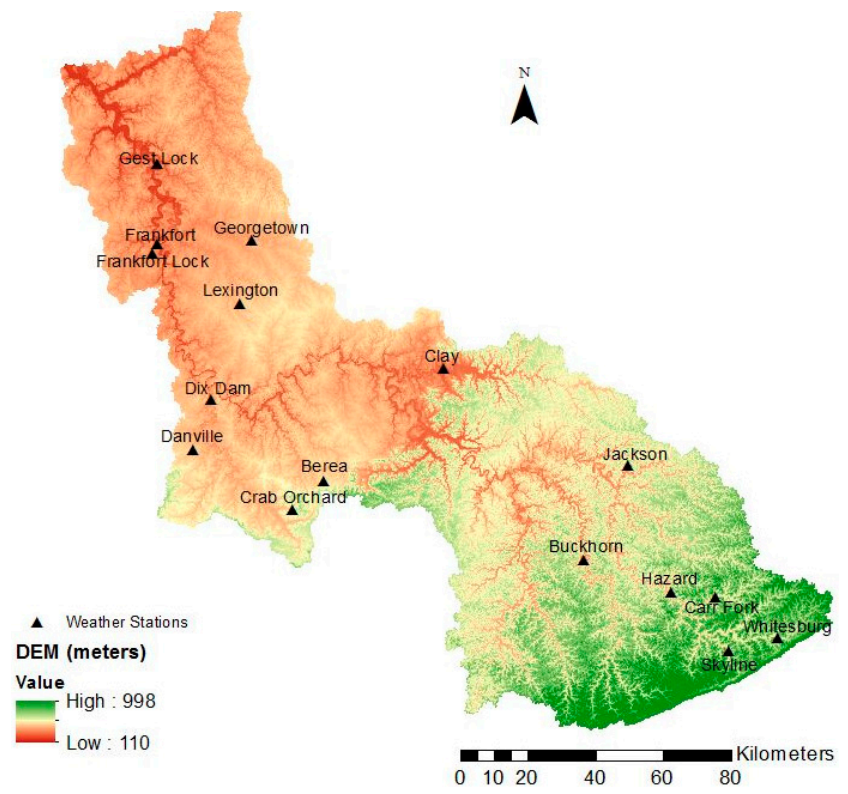

(a)

Figure 2. Cont. 


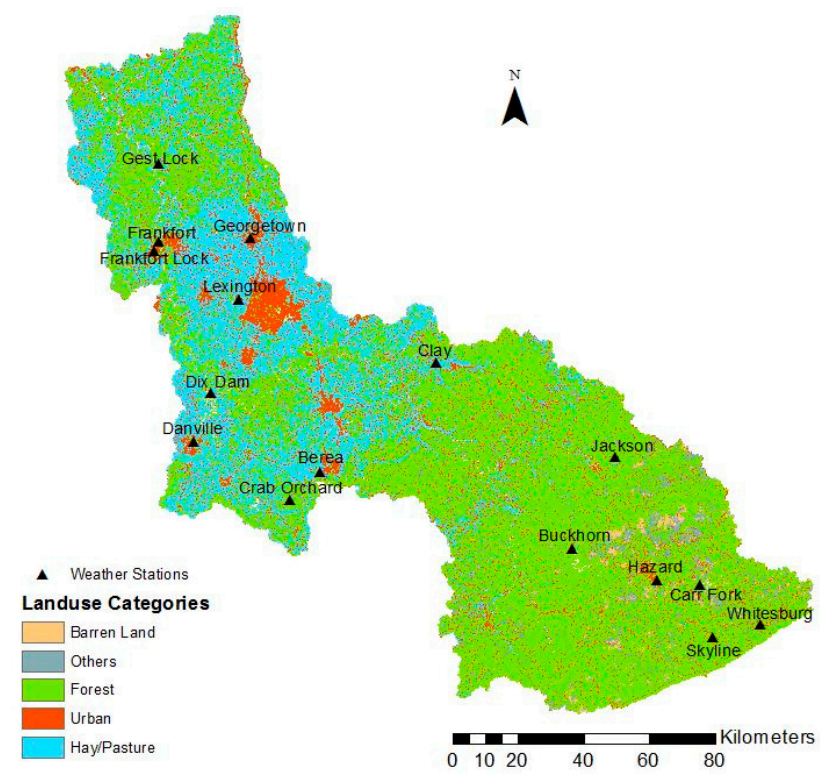

(b)

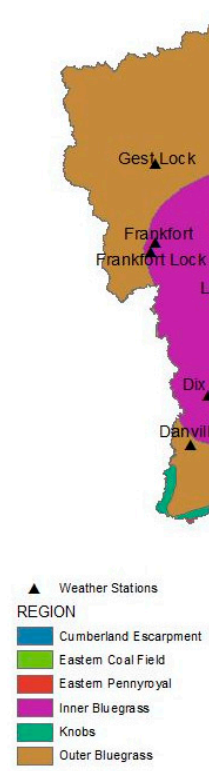

A 
broadly consists of a comparison of GCM outputs with corresponding observations over a common period. The results of the comparison are used to adjust projections to achieve greater agreement with the historical data and thus a more realistic representation of the spatial domain of interest [44,45]. The SD step involves interpolating the bias-corrected GCM outputs to higher-resolution grids by utilizing the spatial detail provided by observationally-derived datasets. Ning et al. [46] used the BCSD method to analyze projected changes in extreme climatic events over the northeastern United States and provided a detailed description of procedures used for bias correction and spatial disaggregation of GCM outputs. It is to be noted that, as reported by [31], this type of downscaling method does not guarantee close correspondence between short-term (days or weeks) behavior in observations and GCM projections. Additionally, elevation differences are unaccounted for in the interpolation algorithm. Even so, the quantile mapping technique [47] used in BCSD to eliminate bias in daily precipitation data resulted in monthly and annual precipitation predictions that agreed very well with observations [48]. In the present study, only the GCM grid points located nearest to the ground-based weather stations were considered in comparing GCM outputs to historical data.

Table 2. Description of CMIP5 models used in this study.

\begin{tabular}{|c|c|c|c|}
\hline Model Name & Institution & $\begin{array}{c}\text { Spatial } \\
\text { Resolution }\end{array}$ & Reference \\
\hline ACCESS 1-0 & Commonwealth Scientific and Industrial Research Organization, Australia & $1.9^{\circ} \times 1.2^{\circ}$ & Lewis and Karoly [49] \\
\hline BCC-CSM 1.1 & Beijing Climate Center, China Meteorological Administration, China & $2.8^{\circ} \times 2.8^{\circ}$ & Xin et al. [50] \\
\hline CCSM4 & National Center for Atmospheric Research, United States & $1.25^{\circ} \times 0.94^{\circ}$ & Gent et al. [51] \\
\hline CNRM-CM5 & National Center for Meteorological Research, France & $1.4^{\circ} \times 1.4^{\circ}$ & Voldoire et al. [52] \\
\hline GFDL-ESM2G & NOAA/Geophysical Fluid Dynamics Laboratory, United States & $2.5^{\circ} \times 2.0^{\circ}$ & Donner et al. [53] \\
\hline HadGEM2-CC & Met Office Hadley Center, United Kingdom & $1.9^{\circ} \times 1.2^{\circ}$ & Jones et al. [54] \\
\hline IPSL-CM5A-MR & L'Institut Pierre-Simon Laplace, France & $2.5^{\circ} \times 1.25^{\circ}$ & Dufresne et al. [55] \\
\hline MIROC5 & $\begin{array}{l}\text { Japan Agency for Marine-Earth Sciences and Technology, Atmosphere and } \\
\text { Ocean Research and National Institute for Environmental Studies, Japan }\end{array}$ & $1.4^{\circ} \times 1.4^{\circ}$ & Watanabe et al. [56] \\
\hline MIROC-ESM & $\begin{array}{l}\text { Japan Agency for Marine-Earth Sciences and Technology, Atmosphere and } \\
\text { Ocean Research and National Institute for Environmental Studies, Japan }\end{array}$ & $2.8^{\circ} \times 2.8^{\circ}$ & Watanabe et al. [56] \\
\hline NorESM1-M & Norwegian Climate Center, Norway & $2.5^{\circ} \times 1.8^{\circ}$ & Bentsen et al. [57] \\
\hline
\end{tabular}

\subsection{Extreme Precipitation Indices}

Following the joint recommendation of World Metrological Organization Commission for Climatology (CCI), World Climate Research Programme project on Climate Variability and Predictability, several extreme precipitation indices have been used in recent studies to characterize precipitation $[58,59]$. This study considered six of these indices as relevant to the basin and its potential hydrologic issues in terms of describing depth, duration and intensity for precipitation events up to a moderately extreme nature:

1. The total precipitation in wet days (days having $\geq 1 \mathrm{~mm}$ precipitation) (PRCPTOT, $\mathrm{mm}$ )

2. The maximum length of dry periods (CDD, days)

3. The maximum length of wet periods (CWD days)

4. Number of days in a year with precipitation $\geq 20 \mathrm{~mm}$ (R20 $\mathrm{mm}$, days)

5. The annual maximum precipitation over five consecutive days (RX5day, $\mathrm{mm}$ )

6. The simple daily precipitation intensity (SDII, mm/day), calculated as PRCPTOT/(number of wet days)

The R package Climdex [60] was used to calculate these indices from the daily time series data produced from each GCM, which were subsequently averaged over all GCMs. The final index used in the study was the Standardized Precipitation Index (SPI) [61], which has recently been recommended as a standard drought index by the World Metrological Organization (WMO) [62]. For a given duration, the SPI is calculated as the standard normal deviate of the distribution of cumulative rainfall for that duration; hence, negative values of SPI represent relative drought conditions with drought severity increasing with more negative SPI values (e.g., an SPI $\leq-2$ can be considered an extreme drought; 
Table 3). Following Wang et al. [63], a 12-month duration (ending in December) was used for SPI computations to reflect longer-term conditions using the SPI package in R [64] statistical software.

Table 3. Drought classification using the SPI index [61].

\begin{tabular}{ccc}
\hline Level & Drought Category & SPI Values \\
\hline 0 & Non-drought & $0 \leq \mathrm{SPI}$ \\
1 & Mild drought & $-1.0<\mathrm{SPI}<0$ \\
2 & Moderate drought & $-1.5<\mathrm{SPI}<-1.0$ \\
3 & Severe drought & $-2.0<\mathrm{SPI}<-1.5$ \\
4 & Extreme drought & $\mathrm{SPI} \leq-2.0$ \\
\hline
\end{tabular}

\subsection{Trend Detection}

Prior to trend detection, total annual rainfall was examined for the presence of serial correlation, since serial correlation can adversely affect the quality of trend estimates of the indices such as PRCPTOT and SPI. However, none of stations was found as having significantly serially correlated data.

Trends were estimated at annual scale for the extreme precipitation indices using the nonparametric Mann-Kendall test [65]. The Mann-Kendall test has the advantage of being relatively unaffected by outliers and is not restricted to a particular sample distribution. Trends were spatially interpolated for graphical representation purposes from the point estimates using the surface inverse-distance-weighted (IDW) algorithm in the ArcGIS framework. Interpolation techniques that account for elevation variations have been shown (Xu et al. [66]) to reduce the mean absolute error of daily precipitation interpolations from $7 \%$ to $18 \%$ relative to inverse distance weighting. Maps derived from the two methods were very similar in major regards; however, the influence of individual stations on the maps was greater for IDW than when altitude was accounted for. While these results were obtained for daily precipitation rather than precipitation indices, the indices might exhibit a similarly high degree of station influence when mapped using the IDW technique.

\section{Results and Discussion}

\subsection{GCM Performance Evaluation}

Performance of the GCMs and ensemble mean in terms of total annual precipitation is indicated in Table 4, in which the mean absolute error (MAE) and normalized standard deviation (NSD) are used as metrics $[40,67,68]$. Near-unity values of MAE and NSD imply relatively high accuracy and similar variation, respectively, of projections relative to observations. On the basis of both MAE and NSD values, then, the GFDL-ESM2G model can be considered as demonstrating best overall performance (Table 4). While the performance of the ensemble mean was better than that of any individual model, the ensemble mean was also associated with the lowest NSD, reflecting the damping effect of averaging projections across models. This is indicated in Figure 3, in which the GCM ensemble mean is shown to be very comparable to observations in terms of average magnitude, even if not reflecting the same degree of yearly variation. This comparison argues in favor of the ensemble mean if the interest is primarily in magnitudes (as may apply to studies involving data projections), though the variation in projections might be substantially lower than observed.

Figure 4 indicates that, relative to observations, GCM outputs were relatively consistent across models and comparable to observations. Across all GCMs and months, Mean Absolute Error (MAE) $[40,67,68]$ ranged from 0.22 to $14.16 \mathrm{~mm}$. Across all months, MAE was lowest for the HadGEM2-CC $(4.16 \mathrm{~mm})$ and highest for the MIROC5 $(7.40 \mathrm{~mm})$ GCMs. Across all GCMs, overall performance was best for February $(\mathrm{MAE}=1.74 \mathrm{~mm}$ ) and worst for October (MAE $=10.30 \mathrm{~mm}$ ). Based on $t$-tests applied to monthly results, the ensemble mean was in no case significantly $(p<0.05)$ different from the observed mean, indicating that the ensemble mean successfully reflects observed total monthly precipitation. 


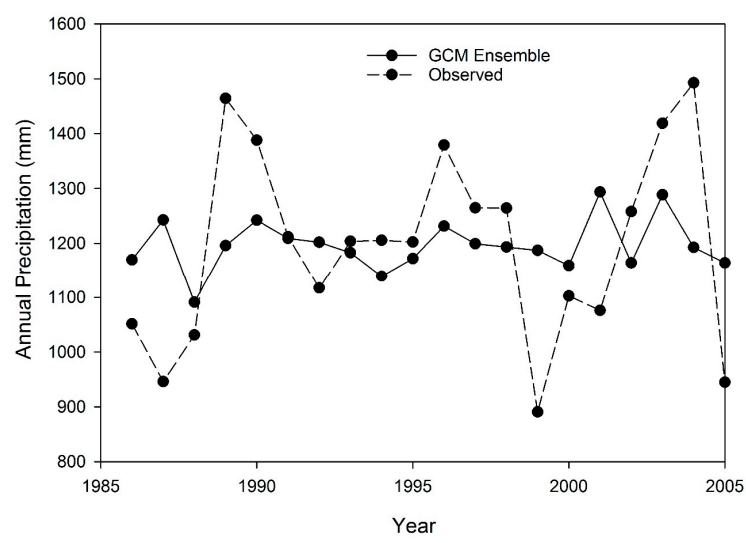

Figure 3. GCM ensemble and observed annual precipitation for the time frame of 1986-2005.

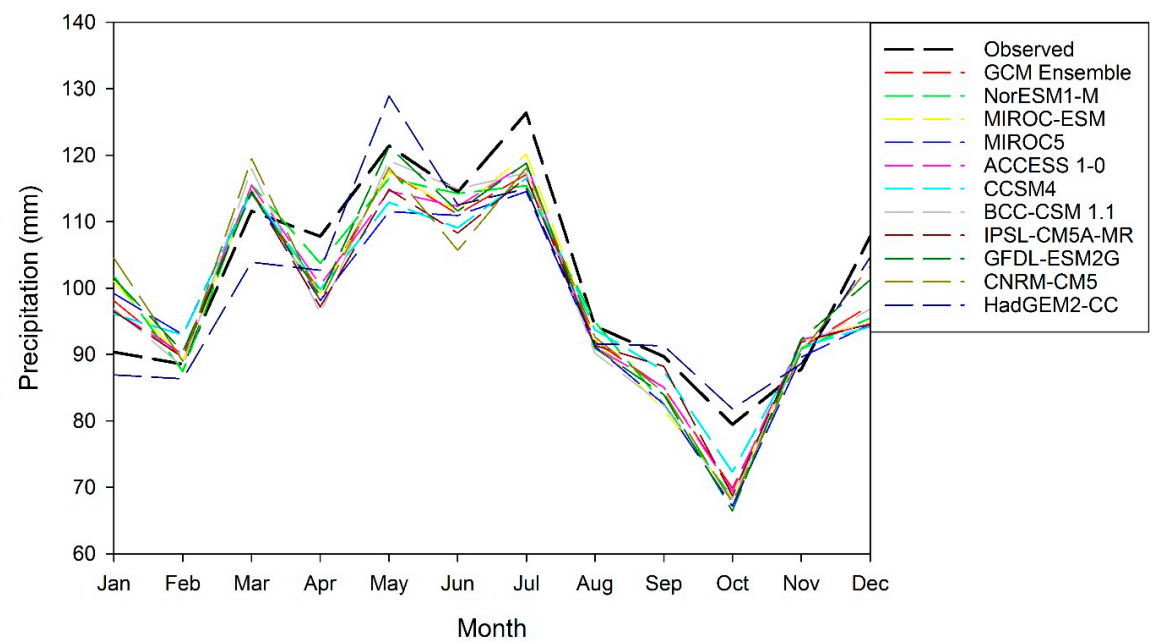

Figure 4. Observed and GCM simulated monthly precipitation in the Kentucky River Watershed (1986-2005).

Table 4. Mean Absolute Error (MAE) and Normalized Standard Deviation (NSD) of GCM simulated annual precipitation in the Kentucky River Watershed (1986-2005).

\begin{tabular}{ccc}
\hline Model & MAE $(\mathbf{m m})$ & NSD $(\mathbf{m m})$ \\
\hline ACCESS 1-0 & 206.65 & 0.97 \\
BCC-CSM 1.1 & 164.51 & 0.84 \\
CCSM4 & 202.35 & 0.92 \\
CNRM-CM5 & 177.12 & 1.18 \\
GFDL-ESM2G & 136.21 & 1.02 \\
HadGEM2-CC & 140.58 & 0.78 \\
IPSL-CM5A-MR & 203.89 & 0.70 \\
MIROC5 & 169.37 & 0.98 \\
MIROC-ESM & 206.87 & 0.92 \\
NorESM1-M & 164.67 & 0.69 \\
Ensemble Mean & 134.73 & 0.27 \\
\hline
\end{tabular}

\subsection{Trend Analysis of Extreme Indices}

Table 5 lists the annual mean values of the studied indices along with the trend slope estimates identified from baseline period data, each of which will be discussed individually in the coming subsections. Only a relatively small proportion $(\approx 11 \%)$ of the trends were statistically significant $(p<0.05)$; all stations exhibiting a statistically significant trend for any of the indices were located in the central and northern portions of the basin (Clay station and north). The indices PRCPTOT, CWD 
and SDII demonstrated significant trends for the highest number of stations (three each), whereas trends in RX5day and SPI were not significant for any of the stations. Significant trends were identified for four of the seven indices for the Clay station, followed by three for the Lexington station.

Table 5. Mean annual index values with standard deviation and Sen slope estimates. Bold values indicate a significant $(p<0.05)$ trend.

\begin{tabular}{|c|c|c|c|c|c|c|c|}
\hline \multirow{2}{*}{ Stations } & $\begin{array}{l}\text { PRCPTOT } \\
(\mathrm{mm})\end{array}$ & $\begin{array}{l}\text { CDD } \\
\text { (Days) }\end{array}$ & $\begin{array}{l}\text { CWD } \\
\text { (Days) }\end{array}$ & $\begin{array}{l}\text { R20mm } \\
\text { (Days) }\end{array}$ & $\begin{array}{l}\text { RX5day } \\
\text { (mm) }\end{array}$ & $\begin{array}{c}\text { SDII } \\
(\mathrm{mm} / \text { Day })\end{array}$ & SPI \\
\hline & $\begin{array}{c}\text { Trend } \\
(\mathrm{mm} / \text { Year) }\end{array}$ & $\begin{array}{c}\text { Trend } \\
\text { (Days/Year) }\end{array}$ & $\begin{array}{c}\text { Trend } \\
\text { (Days/Year) }\end{array}$ & $\begin{array}{c}\text { Trend } \\
\text { (Days/Year) }\end{array}$ & $\begin{array}{c}\text { Trend } \\
(\mathrm{mm} / \text { Year) }\end{array}$ & $\begin{array}{c}\text { Trend } \\
\text { (mm/Day/Year) }\end{array}$ & $\begin{array}{l}\text { Trend (SPI } \\
\text { Value/Year) }\end{array}$ \\
\hline \multicolumn{8}{|l|}{ Whitesburg } \\
\hline Mean & $1284 \pm 185$ & $13.5 \pm 3.3$ & $9.6 \pm 2.6$ & $14.0 \pm 4.3$ & $101 \pm 25$ & $8.0 \pm 1.2$ & $0.0 \pm 1.2$ \\
\hline Trend & -0.97 & -0.04 & 0.00 & 0.08 & 0.50 & 0.04 & -0.01 \\
\hline \multicolumn{8}{|l|}{ Skyline } \\
\hline Mean & $1221 \pm 197$ & $15 \pm 4$ & $6.0 \pm 1.5$ & $16.6 \pm 4.5$ & $97 \pm 24$ & $9.8 \pm 1.1$ & $0.0 \pm 1.1$ \\
\hline Trend & 4.50 & -0.09 & 0.03 & 0.05 & 0.51 & 0.00 & -0.02 \\
\hline \multicolumn{8}{|l|}{ Carr Fork } \\
\hline Mean & $1143 \pm 225$ & $17.1 \pm 4.7$ & $5.9 \pm 2.1$ & $14.8 \pm 5.6$ & $95 \pm 29$ & $9.6 \pm 1.6$ & $0.0 \pm 1.2$ \\
\hline Trend & 0.22 & 0.00 & 0.00 & -0.05 & 0.25 & -0.02 & -0.00 \\
\hline \multicolumn{8}{|l|}{ Hazard } \\
\hline Mean & $1278 \pm 221$ & $16.7 \pm 3.9$ & $5.9 \pm 1.3$ & $18.4 \pm 5.1$ & $111 \pm 35$ & $10.7 \pm 1.3$ & $0.0 \pm 1$ \\
\hline Trend & 7.78 & 0.00 & 0.00 & 0.18 & 0.71 & 0.04 & -0.02 \\
\hline \multicolumn{8}{|l|}{ Buckhorn } \\
\hline Mean & $1249 \pm 217$ & $16.4 \pm 4.3$ & $7.6 \pm 2.6$ & $15.6 \pm 6.7$ & $101 \pm 23$ & $9.2 \pm 1.7$ & $0.0 \pm 1.1$ \\
\hline Trend & 7.92 & -0.04 & 0.00 & 0.17 & 0.50 & 0.04 & -0.01 \\
\hline \multicolumn{8}{|l|}{ Jackson } \\
\hline Mean & $1260 \pm 213$ & $16.3 \pm 4.5$ & $5.9 \pm 2.0$ & $18.9 \pm 6.0$ & $112 \pm 27$ & $10.7 \pm 1.5$ & $0.0 \pm 1.1$ \\
\hline Trend & 2.30 & 0.00 & 0.00 & 0.00 & -0.70 & 0.00 & -0.01 \\
\hline \multicolumn{8}{|l|}{ Crab Orchard } \\
\hline Mean & $1230 \pm 199$ & $19.4 \pm 5.4$ & $6.0 \pm 1.8$ & $19.4 \pm 4.8$ & $72 \pm 41$ & $11.8 \pm 1.8$ & $0.0 \pm 1.3$ \\
\hline Trend & 6.81 & 0.00 & 0.04 & 0.00 & 0.08 & 0.05 & -0.00 \\
\hline \multicolumn{8}{|l|}{ Berea } \\
\hline Mean & $1182 \pm 194$ & $15.2 \pm 3.0$ & $8.4 \pm 2.4$ & $13.4 \pm 6.3$ & $105 \pm 30$ & $8.8 \pm 2.2$ & $0.0 \pm 1.2$ \\
\hline Trend & 2.51 & 0.04 & 0.08 & -0.21 & -0.94 & -0.06 & -0.01 \\
\hline \multicolumn{8}{|l|}{ Danville } \\
\hline Mean & $1217 \pm 246$ & $19.0 \pm 5.7$ & $5.4 \pm 1.6$ & $18.4 \pm 5.0$ & $123 \pm 42$ & $11.8 \pm 1.9$ & $0.0 \pm 1.2$ \\
\hline Trend & 2.08 & 0.13 & 0.00 & 0.00 & 0.10 & -0.03 & -0.02 \\
\hline \multicolumn{8}{|l|}{ Dix Dam } \\
\hline Mean & $1107 \pm 250$ & $20.6 \pm 7.6$ & $5.7 \pm 1.6$ & $16.2 \pm 4.8$ & $118 \pm 39$ & $11.05 \pm 1.6$ & $0.0 \pm 1.2$ \\
\hline Trend & -0.21 & 0.16 & 0.00 & 0.00 & -0.35 & -0.01 & -0.02 \\
\hline \multicolumn{8}{|l|}{ Clay } \\
\hline Mean & $1169 \pm 242$ & $21.6 \pm 8.0$ & $5.1 \pm 1.7$ & $18.4 \pm 5.3$ & $122 \pm 38$ & $13.5 \pm 2.9$ & $0.0 \pm 1.1$ \\
\hline Trend & 15.68 & -0.34 & 0.14 & 0.14 & -0.21 & -0.20 & -0.00 \\
\hline \multicolumn{8}{|l|}{ Lexington } \\
\hline Mean & $1208 \pm 227$ & $17.7 \pm 4.3$ & $5.1 \pm 1.1$ & $18.2 \pm 5.2$ & $122 \pm 35$ & $11.6 \pm 1.4$ & $0.0 \pm 1.2$ \\
\hline Trend & 10.63 & 0.00 & 0.00 & 0.25 & 1.25 & 0.07 & -0.07 \\
\hline \multicolumn{8}{|l|}{ Frankfort Lock } \\
\hline Mean & $1156 \pm 202$ & $16.7 \pm 3.3$ & $6.8 \pm 2.5$ & $14.4 \pm 5.8$ & $107 \pm 29$ & $9.9 \pm 2.3$ & $0.0 \pm 1.2$ \\
\hline Trend & 7.54 & -0.10 & 0.15 & -0.20 & 0.03 & -0.16 & -0.01 \\
\hline \multicolumn{8}{|l|}{ Frankfort } \\
\hline Mean & $1239 \pm 248$ & $18.6 \pm 5.3$ & $6.0 \pm 1.7$ & $18.9 \pm 5.0$ & $120 \pm 41$ & $11.8 \pm 1.4$ & $0.0 \pm 1.2$ \\
\hline Trend & 1.34 & -0.10 & 0.00 & 0.00 & 0.25 & -0.02 & -0.00 \\
\hline \multicolumn{8}{|l|}{ Georgetown } \\
\hline Mean & $1212 \pm 232$ & $16.6 \pm 4.4$ & $6.3 \pm 2.0$ & $17.7 \pm 5.6$ & $116 \pm 38$ & $10.8 \pm 1.7$ & $0.0 \pm 1.2$ \\
\hline Trend & 12.51 & -0.09 & 0.00 & 0.27 & 0.74 & 0.07 & -0.01 \\
\hline \multicolumn{8}{|l|}{ Gest Lock } \\
\hline Mean & $1139 \pm 199$ & $18.2 \pm 7.0$ & $6.9 \pm 2.4$ & $14.1 \pm 5.7$ & $109 \pm 39$ & $9.8 \pm 2.5$ & $0.0 \pm 1.2$ \\
\hline Trend & 7.62 & -0.05 & 0.12 & -0.18 & 0.27 & -0.12 & -0.03 \\
\hline \multicolumn{8}{|l|}{ Overall } \\
\hline Mean & $1206 \pm 52$ & $17.4 \pm 2.1$ & $6.4 \pm 1.2$ & $16.7 \pm 2.1$ & $108 \pm 13$ & $10.6 \pm 1.4$ & $0.0 \pm 0.92$ \\
\hline Trend & 5.51 & -0.03 & 0.03 & 0.03 & 0.19 & -0.02 & -0.02 \\
\hline
\end{tabular}




\subsection{PRCPTOT}

The majority of stations (87.5\%) demonstrated an increasing trend in PRCPTOT, suggestive of an overall wetting trend over the baseline period. Trends in PRCPTOT were significant for three of the 16 stations (Clay, Georgetown and Lexington, Table 5) in the north-central portion of the watershed (Figure 5), ranging from 10.6 (Lexington) to 15.7 (Clay) mm/year.

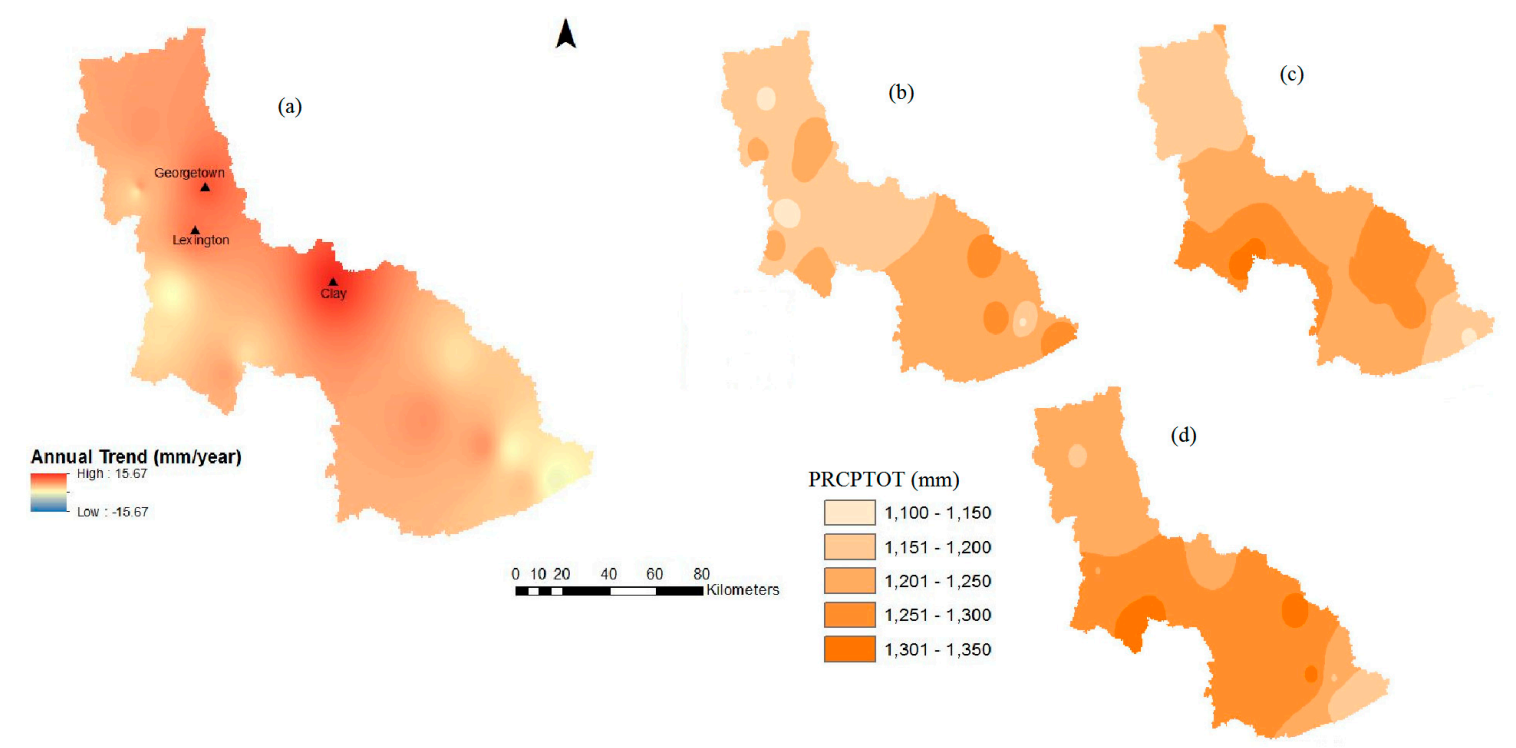

Figure 5. Spatial distribution of PRCPTOT (a) trend and mean values under: (b) baseline; (c) late-century RCP 4.5; and (d) late-century RCP 8.5, in the Kentucky River Basin. Filled triangles indicate a statistically significant $(p<0.05)$ trend.

The spatial distribution of PRCPTOT and its trends are given in Figure 5. Late-century projections for RCPs 4.5 and 8.5 are similar in the sense that both indicate modest basin-wide average increases in PRCPTOT (7 mm for RCP 4.5 and $29 \mathrm{~mm}$ for RCP 8.5), and except for the extreme southeastern portion (with decreases of $145-165 \mathrm{~mm}$ relative to the baseline period), most prominently in the southern portion of the watershed. In some cases, however, the projections are spatially inconsistent with baseline PRCPTOT values (Figure 5b) and trends (Figure 5a). The Lexington and Georgetown stations, for example, had significantly increasing trends over the baseline period. Late-century projections, however, reflect a decrease (relative to the baseline period) of 8-36 $\mathrm{mm}$ for Georgetown and a net change of only $-15-13 \mathrm{~mm}$ for Lexington. Similarly, the Clay station (which had the highest trend) is unremarkable in RCP 4.5 projections (Figure $5 \mathrm{c}$ ) and has a lower PRCPTOT than the surrounding area in RCP 8.5 projections (Figure $5 \mathrm{~d}$ ).

\section{4. $C D D$ and $C W D$}

Magnitudes of trends in CDD and CWD over the baseline period were generally low and significant in only four instances involving three stations (Clay, Frankfort Lock and Gest Lock). Figure 6a indicates generally negative trends in CDD in the northeastern portion of the basin, with (usually weakly) positive trends elsewhere. Figure $6 \mathrm{~b}$ demonstrates that the northern portion of the basin had relatively higher CDD values than the southern for baseline conditions, a situation expected to persist according to late-century projections (Figure $6 \mathrm{c}, \mathrm{d}$ ). The late-century projections also indicate basin-wide decreases in CDD, with the areal average decreases ranging from two days (RCP 4.5) to three days (RCP 8.5). The projected decreases are generally consistent with trends identified in the baseline period with the possible exception of the west-central portion. 


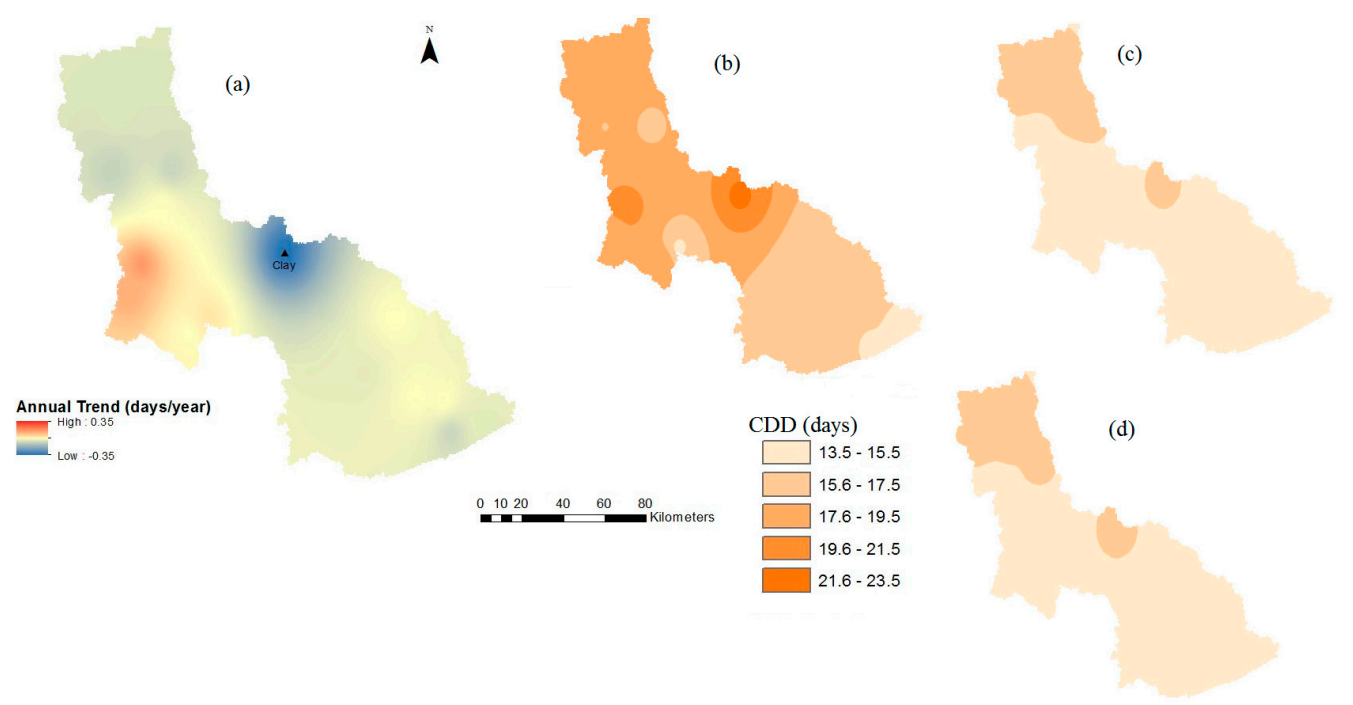

Figure 6. Spatial distribution of CDD (a) trend and mean values under: (b) baseline; (c) late-century RCP 4.5; and (d) late-century RCP 8.5, in the Kentucky River Basin. Filled triangles indicate a statistically significant $(p<0.05)$ trend.

Findings regarding CWD were generally complementary to those for CDD in that decreases in CDD were accompanied by increases in CWD. Trends in CWD were uniformly positive, strongest in the central and northern portions of the basin (Clay, Frankfort Lock and Gest Lock stations) and weaker elsewhere (Figure 7a). This general result is reflected in the late-century projections (Figure 7c,d) where, relative to baseline conditions, CWD is anticipated to increase (particularly in the southern portion) throughout the basin. Late-century projections indicate an increase in CWD averaging 3 days across the basin, concentrated primarily in the southern portion for RCP 4.5 and somewhat more uniformly-distributed for RCP 8.5. Similar to the situation of PRCPTOT, the relatively high baseline trend in CWD for the Clay is not reflected in CWD projections (Figure $5 \mathrm{c}, \mathrm{d}$ ). Taken together, the CDD and CWD results suggest basin-wide decreases in runs of dry days along with increases in runs of wet days in the late-century period. Schoof [69] investigated changes in extreme precipitation indices for contiguous US and reported very similar projected changes in CDD and CWD for the time frame of 2066-2095 around the study area.

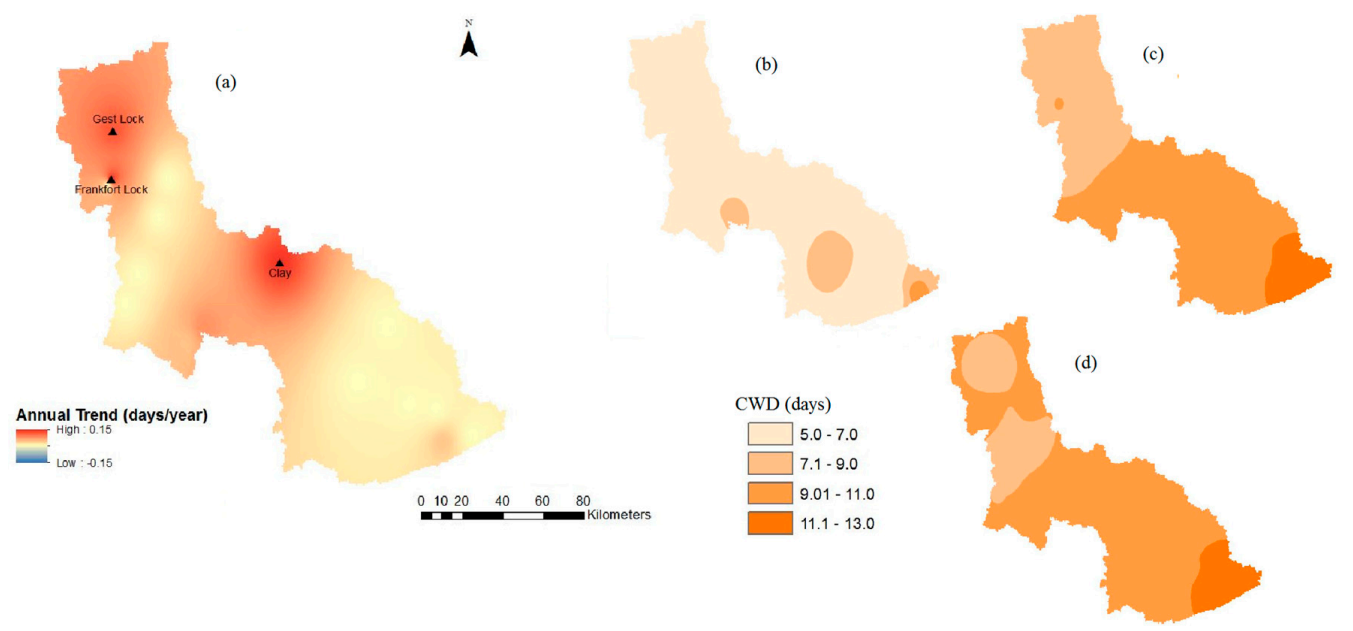

Figure 7. Spatial distribution of CWD (a) trend and mean values under: (b) baseline; (c) late-century RCP 4.5; and (d) late-century RCP 8.5, in the Kentucky River Basin. Filled triangles indicate a statistically significant $(p<0.05)$ trend. 


\section{5. $R 20 \mathrm{~mm}$}

Two stations (Georgetown and Lexington) indicated significant trends in R20mm (0.27 and 0.25 days /year, respectively); the remainder of the basin was found to have an approximately equal distribution of weakly positive and negative trends (Figure 8a). It is noteworthy that the Georgetown and Lexington stations are nearest in proximity to the most heavily urbanized portion of the basin; Misra et al. [70] suggested a linkage between urbanized areas in the US and increasing trends in indices such as daily maximum rainfall intensity and number of days with heavy precipitation, a finding more recently corroborated by Zilli et al. [71].

Late-century projections reflect basin-wide decreases of 4-5 days in R20mm (Figure 8c,d). Although the Georgetown/Lexington area is, consistent with baseline period trends, in the region of highest projected $\mathrm{R} 20 \mathrm{~mm}$, late-century projections indicate decreases for these stations as well. The results in this case indicate spatial consistency with baseline period analysis, but not trend consistency. This finding is suggestive that, rather than indicating reversal of contemporarily-assessed trends, the GCM projections might be reflecting the issues discussed by Lafon et al. [30]; namely, underestimation of rainfall intensities.

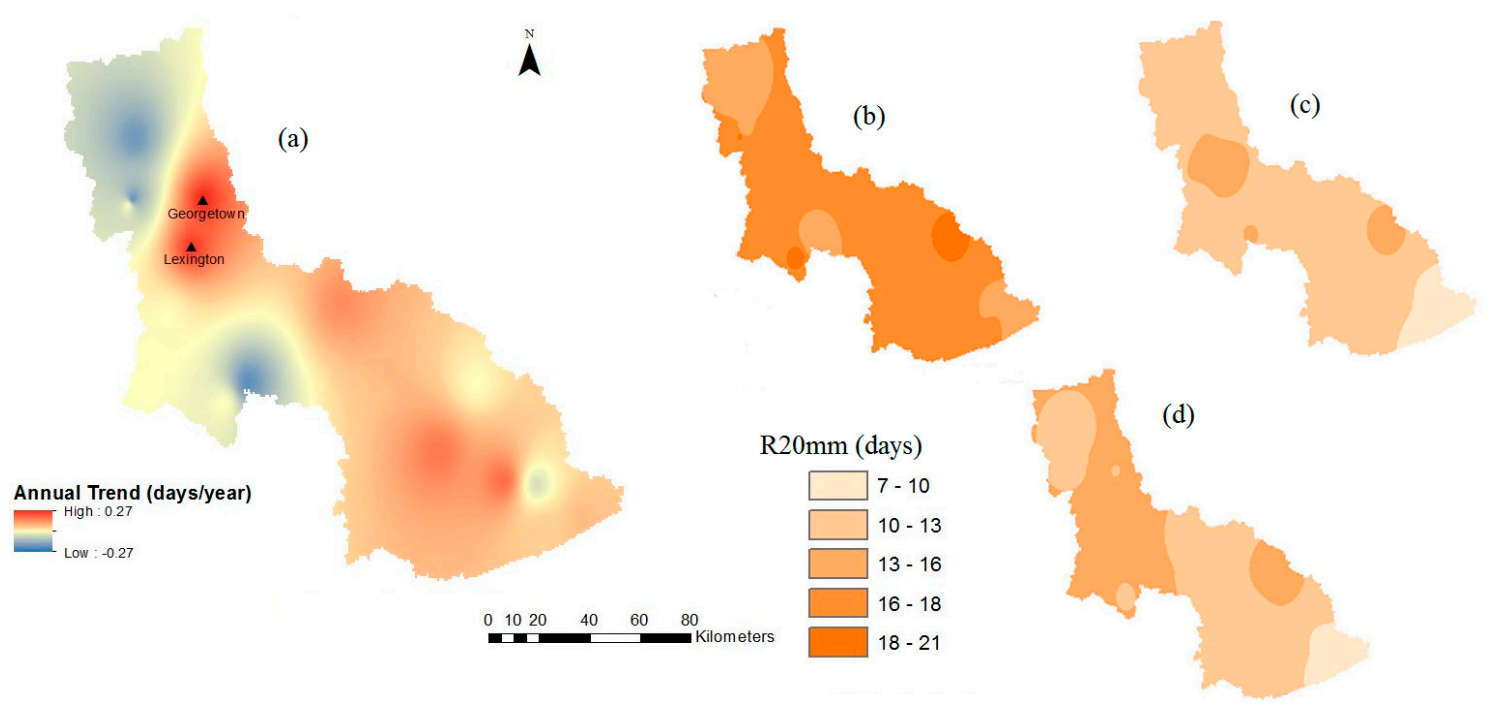

Figure 8. Spatial distribution of R20mm (a) trend and mean values under: (b) baseline; (c) late-century RCP 4.5; and (d) late-century RCP 8.5, in the Kentucky River Basin. Filled triangles indicate a statistically significant $(p<0.05)$ trend.

\subsection{RX5day}

Analysis of baseline period data indicated a tendency toward decreasing trends in RX5day in the central portion of the basin and increasing trends elsewhere (Figure 9a). However, no station demonstrated a statistically significant trend in annual maximum five-day rainfall. Consistent with this result, late-century projections indicated modest or very slight changes in RX5day ( $<7 \%$ decrease for RCP 4.5, <1\% increase for RCP 8.5) relative to the baseline period (Figure 9b-d). Shifts in the spatial distribution of RX5day across the basin are projected, however, with higher values in the north for the late-century. 


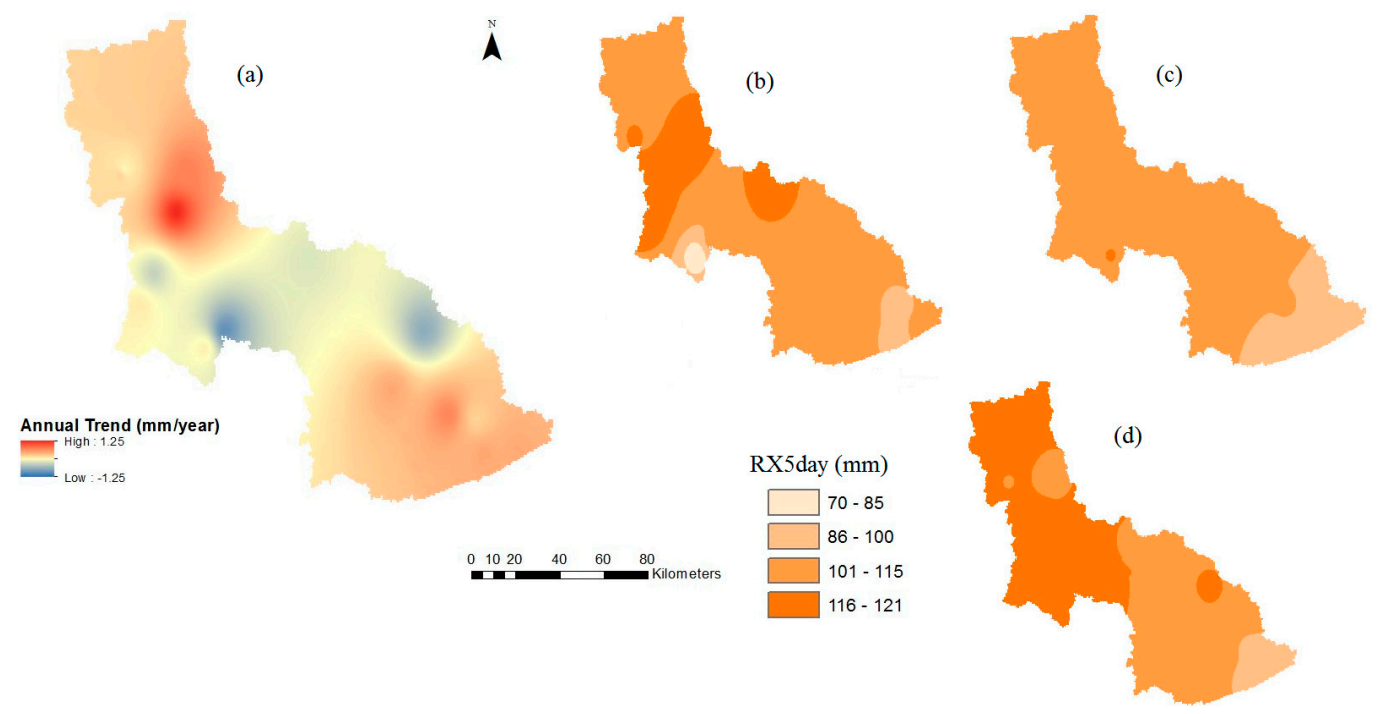

Figure 9. Spatial distribution of RX5day (a) trend and mean values under: (b) baseline; (c) late-century RCP 4.5; and (d) late-century RCP 8.5, in the Kentucky River Basin.

\subsection{SDII}

Baseline period trends in SDII were mixed; the statistically significant $(p<0.05)$ trends were negative for two stations (Clay and Frankfort) and positive for the Lexington Station (Figure 10a), and inconsequential overall (Table 5). Projections for RCP 4.5 and 8.5 (Figure 10c,d), however, reflect decreases in SDII throughout the watershed for the late-century period (approximately 3 days for both RCP 4.5 and 8.5). As previously discussed, PRCPTOT was projected to increase (albeit modestly) by late century; this result must therefore necessarily reflect a projected change in annual numbers of wet days. Thus, this finding appears related to results related to CWD, collectively suggesting that either: (a) a currently-weak and mixed trends in SDII (or, more precisely, numbers of wet days) will broadly shift toward the positive direction in the late-century; or (b) the GCM projections contain excessive numbers of wet days.

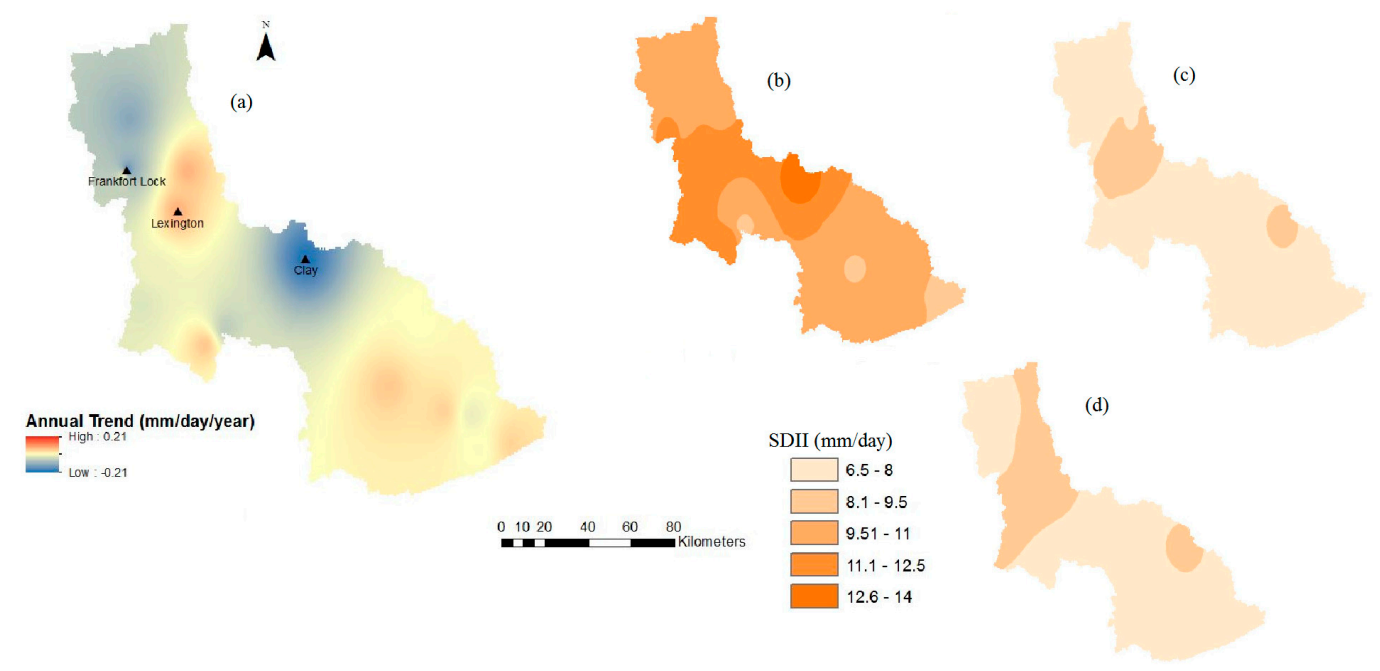

Figure 10. Spatial distribution of SDII (a) trend and mean values under: (b) baseline; (c) late-century RCP 4.5; and (d) late-century RCP 8.5, in the Kentucky River Basin. Filled triangles indicate a statistically significant $(p<0.05)$ trend. 


\subsection{SPI}

While the direction of annual trend in year-ending SPI was in all cases negative, the trend in SPI was not significant $(p<0.05)$ for any of the 16 stations (Figure 11a). In terms of numerical magnitudes (Table 5), SPI values were quite small relative to drought category ranges (Table 3). Furthermore, as a result of the non-linear relationship between total annual rainfall and SPI, variation in annual rainfall (i.e., PRCPTOT) is amplified during SPI computations; this is evident in the relatively high standard deviations of year-ending SPI (Table 5).

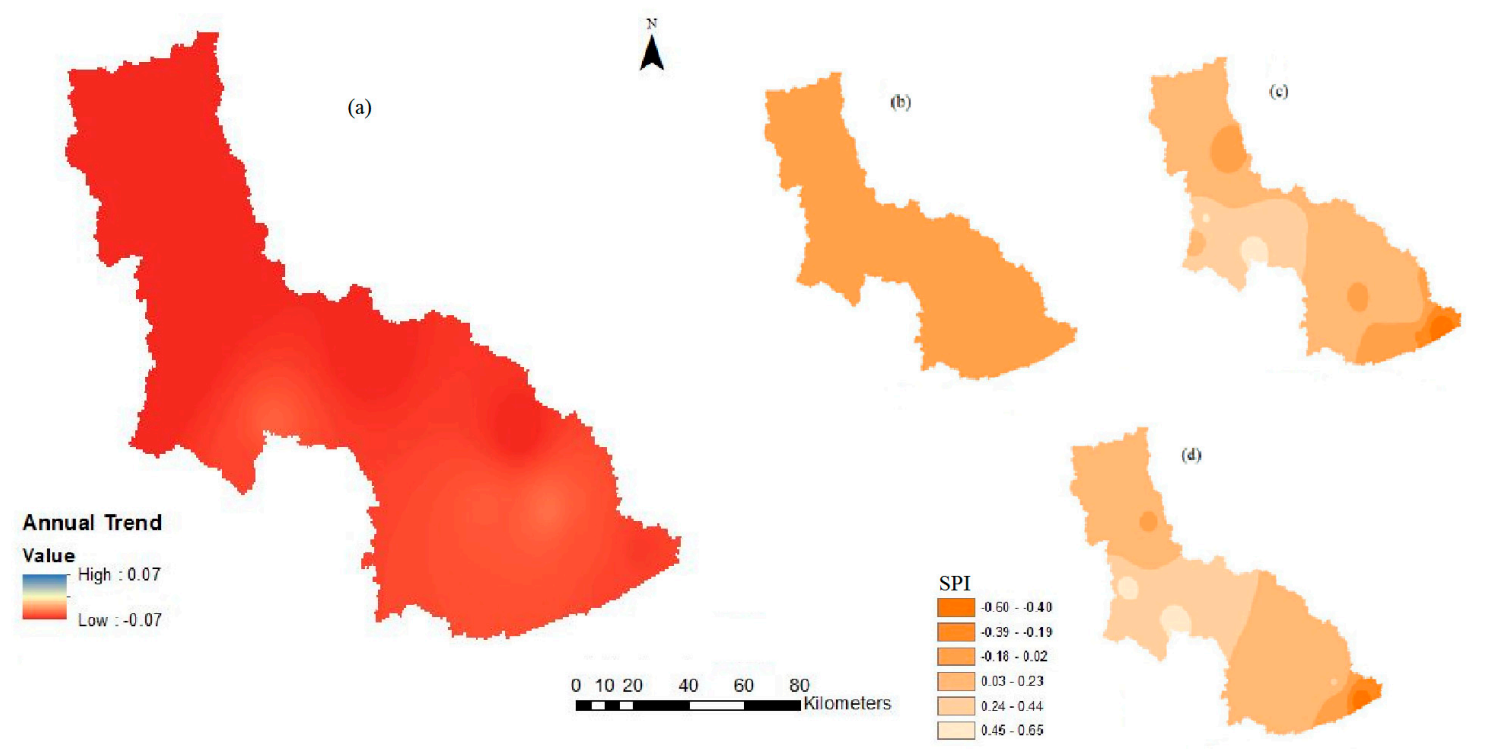

Figure 11. Spatial distribution of SPI (a) trend and mean values under: (b) baseline; (c) late-century RCP 4.5; and (d) late-century RCP 8.5, in the Kentucky River Basin.

Relative to baseline SPI values (Figure 11b; zero by definition), both scenarios project increasing average SPI values (i.e., less drought) that demonstrate spatial variation across the watershed (Figure 11c,d). Projections from RCP 4.5 indicate a late-century basin-wide average SPI of 0.11 , whereas RCP 8.5 indicates an average of 0.17 . Both of these findings are consistent with the earlier-discussed results regarding PRCPTOT, which is also projected to increase modestly in the late-century. Figure 12 indicates a late-century reapportionment of time spent in non-drought and mild drought conditions. For baseline conditions, approximately $86 \%$ of year-ending SPI values were evenly divided between the non-drought and mild drought categories. Late-century projections indicate that the proportion of non-drought and mild drought years will remain similar, but with an increase in non-drought years (to $60 \%-67 \%$, depending on RCP) and a corresponding decrease in mild drought years. The spatial distribution of average late-century SPI projections is similar for the two RCPs, indicating relatively high values in the central portion of the watershed and lower values in the extreme southeast.

Given the annual duration of SPI computations, the findings of this study argue neither for nor against drought conditions that might arise on a smaller time scale (seasons or months). Depending on the future distribution of rainfall throughout the year, operationally-significant transitions in such shorter-duration droughts are possible. Analysis at a higher time resolution might be beneficial in view of the seasonality of some water demands and the related practical implications on water management. 


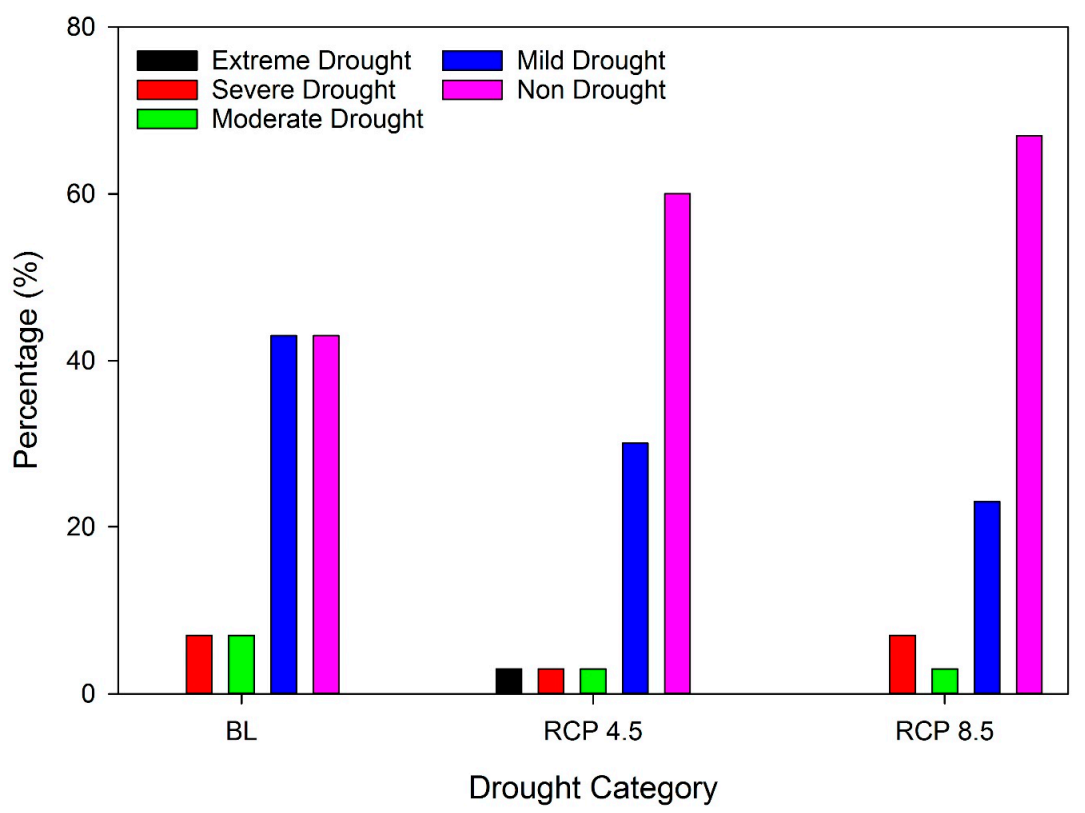

Figure 12. Percentage of time in each drought category under baseline and late-century conditions. (BL denotes baseline).

\section{Summary and Conclusions}

This study used data from 16 GHCN weather stations over the period 1986-2015 (the baseline period) to evaluate spatial variability and trends in precipitation indices for the Kentucky River basin. These findings were then considered alongside projections from 10 CMIP5 GCMs for the period 2070-2099 (late-century period) to assess changes in index magnitudes and spatial distribution as well as consistency with trends identified during the baseline period.

Averaged baseline period findings indicated that the southern portion (with higher elevations and proportion of forest cover) of the basin experienced generally higher PRCPTOT with fewer days separating rainfall events (CDD) and, especially in the extreme southeastern portion, longer runs of days with rainfall $\geq 1 \mathrm{~mm}(\mathrm{CWD})$. The spatial distribution of other indices was generally more uniform; noteworthy variations are more suggestive of microclimate effects (e.g., the Lexington/Georgetown and Clay stations) than systematic spatial trends. Trends in the indices over the baseline period were significant for only about $11 \%$ of the station-index combinations, all in the central and (to a lesser degree) northern portions of the basin, which are generally dominated by pasture/hay and urban land uses. Trends in PRCPTOT were among the most consistent, demonstrating increasing values (up to $15.68 \mathrm{~mm}$ /year) for all but two of the 16 stations and significant for three stations in the north-central portion of the basin. The Lexington and Georgetown stations, both in close proximity to the most heavily urbanized portion of the basin and separated by only about $50 \mathrm{~km}$, had significant trends in $\mathrm{R} 20 \mathrm{~mm}$, indicative of an increasing number of heavy rainfall events over the baseline period. Trends for remaining indices were directionally and spatially mixed to a higher degree, demonstrating less apparent relation to elevation or land use. The Clay station, in particular, was associated with inconsistent (relative to neighboring stations) results, perhaps related to its location near a physiographic region boundary (in the transition between Eastern Coal Fields and Outer Bluegrass, also transitional between dominant land uses), its relatively low elevation within the Kentucky River valley, or both.

Late-century projections for PRCPTOT, CDD, CWD, RX5day and SPI were, in the spatial aggregate, consistent with the trends identified on the basis of baseline data. These projections indicate modest $(<2.5 \%)$ increases in total precipitation on wet $(>1 \mathrm{~mm}$ ) days with decreases (by 2-3 days) in maximum runs of dry days and increases (approximately three days) in maximum runs of wet days. Maximum 
five-day precipitation (RX5day) projections demonstrated more sensitivity to the $\mathrm{RCP}$, ranging from a roughly $7 \%$ decrease for RCP 4.5 to a $1 \%$ increase for RCP 8.5 . Both RCPs project that on the basis of watershed-wide average SPI values, non-drought years will be more-common in the late-century, with mild drought years becoming less common; the proportion of years with more intense drought conditions (moderate, severe or extreme) is projected to remain essentially unchanged from the baseline period. Additional analysis based on a higher level of temporal disaggregation of projections will be required to support water resource management planning and operations that are based on smaller time durations (e.g., semi-annually or seasonally).

It may be noted that the above indices are associated with the "macroweather" (Lovejoy [72]) regime, considered as 5-10 days to 10-30 years. In other words, they are less vulnerable to the challenges of shorter-duration (i.e., the "weather" regime) GCM projections and could have been expected to be of relatively high fidelity. While this appears to have been the overall case, anomalous results occasionally surfaced in the spatial domain. The apparent microclimates in the vicinities of the Lexington/Georgetown and Clay stations, for example, were not evidenced as expected in the projections. This phenomenon is likely an outcome of the GCM output downscaling algorithm and/or the mapping algorithm, especially given the distance and elevation difference between the Clay station and its neighbors.

In the cases of the remaining indices (R20 mm and SDII), late-century projections sometimes stood in contrast to trends identified during the baseline period. The significant baseline period trends in $\mathrm{R} 20 \mathrm{~mm}$, for example, were in the positive direction; projections from both RCPs, however, indicate basin-wide decreases in the late-century period. Similarly, an overall negligible trend was identified for SDII during the baseline period; however, basin-wide decreases were projected for the late-century, including stations for which the SDII trend was statistically significant $(p<0.05)$ and positive. Unlike the previous five indices, R20mm and SDII are highly associated with the "weather" regime with R20mm being a sum individual, not-necessarily-consecutive days and SDII being a function of a similar sum. To a relatively high degree, therefore, the robustness of these indices is dependent on that of daily GCM outputs. For this study, ensemble GCM projections appear to have more wet days, containing fewer instances of moderately severe rainfall, than anticipated on the strength of baseline data analysis. This, in turn, suggests opportunity in terms of improvements to appropriate internal model structure and/or supplementary output processing algorithms.

The inconsistencies between baseline period trends and late-century projections are cautionary; at a minimum, they suggest limitations in reconciling analyses on relatively small temporal and spatial scales to GCM projections, even when those projections are bias-corrected and spatially downscaled. It seems possible that this study's findings with regard to baseline period conditions and trends reflect relatively large influences of small-scale variables such as elevation and land cover, whose relative importance diminishes in the context of relatively low-resolution GCM projections. While scale- and timeframe-related anomalies need not be irreconcilable, their occurrence can represent challenges to those charged with applying low-resolution projections to smaller scales of decision-making and effective management.

Acknowledgments: This is Publication No. 16-05-089 of the Kentucky Agricultural Experiment Station and is published with the approval of the Director. This work is supported by the USDA National Institute of Food and Agriculture (NIFA) Hatch-Multistate Project under 1006093. The authors wish to express gratitude to Darren Ficklin for his help with the climate model data acquisition. We also appreciate the professionalism of the Academic Editor and the insightful comments of the anonymous reviewers, both of which greatly improved the manuscript from its original version.

Author Contributions: The lead author, Somsubhra Chattopadhyay, envisioned the research topic, and collected and analyzed the data as part of his Ph.D. Thesis. Dwayne R. Edwards supervised the research, and supported in interpretation of the results and manuscript preparation. Yao $\mathrm{Yu}$ contributed in formatting data from climate models.

Conflicts of Interest: The authors declare no conflict of interest. 


\section{References}

1. Ficklin, D.L.; Barnhart, B.L. Swat hydrologic model parameter uncertainty and its implications for hydroclimatic projections in snowmelt-dependent watersheds. J. Hydrol. 2014, 519, 2081-2090. [CrossRef]

2. Chattopadhyay, S.; Jha, M.K. Hydrological response due to projected climate variability in Haw River watershed, North Carolina, USA. Hydrol. Sci. J. 2016, 61, 495-506. [CrossRef]

3. Narsimlu, B.; Gosain, A.K.; Chahar, B.R. Assessment of future climate change impacts on water resources of upper Sind River basin, India using SWAT model. Water Resour. Manag. 2013, 27, 3647-3662. [CrossRef]

4. Ashraf, V.S.; Mousavi, S.J.; Abbaspour, K.C.; Srinivasan, R.; Yang, H. Analyses of the impact of climate change on water resources components, drought and wheat yield in semiarid regions: Karkheh River basin in Iran. Hydrol. Process. 2014, 28, 2018-2032. [CrossRef]

5. Mehan, S.; Kannan, N.; Neupane, R.P.; McDaniel, R.; Kumar, S. Climate change impacts on the hydrological processes of a small agricultural watershed. Climate 2016, 4, 56. [CrossRef]

6. Intergovernmental Panel on Climate Change. Climate Change 2013: The Physical Science Basis. Contribution of Working Group I to the Fifth Assessment Report of the Intergovernmental Panel on Climate Change; Stocker, T.F., Qin, D., Plattner, G.K., Tignor, M., Allen, S.K., Boschung, J., Nauels, A., Xia, Y., Bex, C., Midgley, P.M., Eds.; Cambridge University Press: Cambridge, UK, 2013; p. 1535.

7. Hirabayashi, Y.; Mahendran, R.; Koirala, S.; Konoshima, L.; Yamazaki, D.; Watanabe, S.; Kim, H.; Kanae, S. Global flood risk under climate change. Nat. Clim. Chang. 2013, 3, 816-821. [CrossRef]

8. Portmann, R.W.; Solomon, S.; Hegerl, G.C. Spatial and seasonal patterns in climate change, temperatures, and precipitation across the United States. Proc. Natl. Acad. Sci. USA 2009, 106, 7324-7329. [CrossRef] [PubMed]

9. Karl, T.R.; Meehl, G.A.; Peterson, T.C. Global Climate Change Impacts in the United States; Cambridge University Press: Cambridge, UK, 2009.

10. Sayemuzzaman, M.; Jha, M.K. Seasonal and annual precipitation time series trend analysis in North Carolina, United States. Atmos. Res. 2014, 137, 183-194. [CrossRef]

11. Gao, Y.; Fu, J.S.; Drake, J.B.; Liu, Y.; Lamarque, J.F. Projected changes of extreme weather events in the eastern United States based on a high resolution climate modeling system. Environ. Res. Lett. 2012, 7, 044025. [CrossRef]

12. Chattopadhyay, S.; Edwards, D. Long-term trend analysis of precipitation and air temperature for Kentucky, United States. Climate 2016, 4, 10. [CrossRef]

13. Intergovernmental Panel on Climate Change. Managing the Risks of Extreme Events and Disasters to Advance Climate Change Adaptation. A Special Report of Working Groups I and II of the Intergovernmental Panel on Climate Change. Cambridge, 2012. Available online: http://www.ipcc-wg2.gov/SREX/images/ uploads/SREX-All_FINAL.pdf (accessed on 14 April 2016).

14. Ren, Z.; Zhang, M.; Wang, S.; Qiang, F.; Zhu, X.; Dong, L. Changes in daily extreme precipitation events in south China from 1961 to 2011. J. Geogr. Sci. 2015, 25, 58-68. [CrossRef]

15. De Lima, M.I.P.; Santo, F.E.; Ramos, A.M.; Trigo, R.M. Trends and correlations in annual extreme precipitation indices for mainland Portugal, 1941-2007. Theor. Appl. Climatol. 2015, 119, 55-75. [CrossRef]

16. Mondal, A.; Mujumdar, P.P. On the detection of human influence in extreme precipitation over India. J. Hydrol. 2015, 529, 1161-1172. [CrossRef]

17. Kamruzzaman, M.; Beecham, S.; Metcalfe, A.V. Estimation of trends in rainfall extremes with mixed effects models. Atmos. Res. 2016, 168, 24-32. [CrossRef]

18. Roth, M.; Buishand, T.A.; Jongbloed, G. Trends in moderate rainfall extremes: A regional monotone regression approach. J. Clim. 2015, 28, 8760-8769. [CrossRef]

19. Yuan, X.; Wood, E.F.; Luo, L.; Pan, M. A first look at climate forecast system version 2 (cfsv2) for hydrological seasonal prediction. Geophys. Res. Lett. 2011, 38, L13402. [CrossRef]

20. Mearns, L.O.; Lettenmaier, D.P.; McGinnis, S. Uses of results of regional climate model experiments for impacts and adaptation studies: The example of NARCCAP. Curr. Clim. Chang. Rep. 2015, 1, 1-9. [CrossRef]

21. Fu, G.; Liu, Z.; Charles, S.P.; Xu, Z.; Yao, Z. A score-based method for assessing the performance of gcms: A case study of Southeastern Australia. J. Geophys. Res. Atmos. 2013, 118, 4154-4167. [CrossRef]

22. Deser, C.; Phillips, A.; Bourdette, V.; Teng, H. Uncertainty in climate change projections: The role of internal variability. Clim. Dyn. 2012, 38, 527-546. [CrossRef] 
23. Rocheta, E.; Sugiyanto, M.; Johnson, F.; Evans, J.; Sharma, A. How well do general circulation models represent low-frequency rainfall variability? Water Resour. Res. 2014, 50, 2108-2123. [CrossRef]

24. Emori, S.; Hasegawa, A.; Suzuki, T.; Dairaku, K. Validation, parameterization dependence, and future projection of daily precipitation simulated with a high-resolution atmospheric GCM. Geophys. Res. Lett. 2005, 32, 541-544. [CrossRef]

25. Lafon, T.; Dadson, S.; Buys, G.; Prudhomme, C. Bias correction of daily precipitation simulated by a regional climate model: A comparison of methods. Int. J. Climatol. 2013, 33, 1367-1381. [CrossRef]

26. Ines, A.V.M.; Hansen, J.W. Bias correction of daily gcm rainfall for crop simulation studies. Agric. For. Meteorol. 2006, 138, 44-53. [CrossRef]

27. Mahoney, K.; Alexander, M.; Scott, J.D.; Barsugli, J. High-resolution downscaled simulations of warm-season extreme precipitation events in the Colorado front range under past and future climates. J. Clim. 2013, 26, 8671-8689. [CrossRef]

28. Sunyer, M.A.; Hundecha, Y.; Lawrence, D.; Madsen, H.; Willems, P.; Martinkova, M.; Vormoor, K.; Bürger, G.; Hanel, M.; Kriaučiūnienè, J.; et al. Inter-comparison of statistical downscaling methods for projection of extreme precipitation in Europe. Hydrol. Earth Syst. Sci. 2015, 19, 1827-1847. [CrossRef]

29. Johnson, F.; Sharma, A. Measurement of gcm skill in predicting variables relevant for hydroclimatological assessments. J. Clim. 2009, 22, 4373-4382. [CrossRef]

30. Radić, V.; Clarke, G.K.C. Evaluation of ipcc models' performance in simulating late-twentieth-century climatologies and weather patterns over North America. J. Clim. 2011, 24, 5257-5274. [CrossRef]

31. Miao, C.; Duan, Q.; Yang, L.; Borthwick, A.G.L. On the applicability of temperature and precipitation data from CMIP3 for China. PLoS ONE 2012, 7, e44659. [CrossRef] [PubMed]

32. National Drought Mitigation Center. From Too Much to Too Little: How the Central U.S. Drought of 2012 Evolved Out of One of the Most Devastating Floods on Record in 2011. 2012. Available online: http://drought.unl.edu/Portals/0/docs/CentralUSDroughtAssessment2012.pdf (accessed on 17 March 2016).

33. Kentucky River Facts. Available online: http://kyriverkeeper.org/kentucky-river-facts/ (accessed on 18 June 2016).

34. Pierce, D.W.; Cayan, D.R.; Maurer, E.P.; Abatzoglou, J.T.; Hegewisch, K.C. Improved bias correction techniques for hydrological simulations of climate change. J. Hydrometeorol. 2015, 16, 2421-2442. [CrossRef]

35. Li, H.; Sheffield, J.; Wood, E.F. Bias correction of monthly precipitation and temperature fields from intergovernmental panel on climate change AR4 models using equidistant quantile matching. J. Geophys. Res. Atmos. 2010, 115, 985-993. [CrossRef]

36. Schoof, J.T.; Robeson, S.M. Projecting changes in regional temperature and precipitation extremes in the United States. Weather Clim. Extrem. 2016, 11, 28-40. [CrossRef]

37. Guijarro, J.A. User's Guide to Climatol. 2013. Available online: http://www.climatol.eu/climatol-guide.pdf (accessed on 8 January 2016).

38. Jha, M.K.; Gassman, P.W. Changes in hydrology and streamflow as predicted by a modelling experiment forced with climate models. Hydrol. Process. 2014, 28, 2772-2781. [CrossRef]

39. Zhang, Y.; Su, F.; Hao, Z.; Xu, C.; Yu, Z.; Wang, L.; Tong, K. Impact of projected climate change on the hydrology in the headwaters of the Yellow River Basin. Hydrol. Process. 2015, 29, 4379-4397. [CrossRef]

40. Venkataraman, K.; Tummuri, S.; Medina, A.; Perry, J. 21st century drought outlook for major climate divisions of Texas based on CMIP5 multimodel ensemble: Implications for water resource management. J. Hydrol. 2016, 534, 300-316. [CrossRef]

41. Maurer, E.P.; Adam, J.C.; Wood, A.W. Climate model based consensus on the hydrologic impacts of climate change to the Rio Lempa basin of Central America. Hydrol. Earth Syst. Sci. 2009, 13, 183-194. [CrossRef]

42. Bennett, K.E.; Werner, A.T.; Schnorbus, M. Uncertainties in hydrologic and climate change impact analyses in headwater basins of British Columbia. J. Clim. 2012, 25, 5711-5730. [CrossRef]

43. Rana, A.; Moradkhani, H. Spatial, temporal and frequency based climate change assessment in Columbia River basin using multi downscaled-scenarios. Clim. Dyn. 2015, 361-363, 1-22. [CrossRef]

44. Wood, A.W.; Leung, L.R.; Sridhar, V.; Lettenmaier, D.P. Hydrologic implications of dynamical and statistical approaches to downscaling climate model outputs. Clim. Chang. 2004, 62, 189-216. [CrossRef]

45. Thrasher, B.; Maurer, E.P.; McKellar, C.; Duffy, P.B. Technical note: Bias correcting climate model simulated daily temperature extremes with quantile mapping. Hydrol. Earth Syst. Sci. 2012, 16, 3309-3314. [CrossRef] 
46. Ning, L.; Riddle, E.E.; Bradley, R.S. Projected changes in climate extremes over the Northeastern United States. J. Clim. 2015, 28, 3289-3310. [CrossRef]

47. Panofsky, H.A.; Brier, G.W. Some Applications of Statistics to Meteorology; The Pennsylvania State University: University Park, PA, USA, 1968.

48. Coats, R.; Costa-Cabral, M.; Riverson, J.; Reuter, J.; Sahoo, G.; Schladow, G.; Wolfe, B. Projected 21st century trends in hydroclimatology of the Tahoe Basin. Clim. Chang. 2013, 116, 51-69. [CrossRef]

49. Lewis, S.C.; Karoly, D.J. Assessment of forced responses of the Australian Community Climate and Earth System Simulator (ACCESS) 1.3 in CMIP5 historical detection and attribution experiments. Aust. Meteorol. Oceanogr. J. 2014, 64, 87-101.

50. Xiao-Ge, X.; Tong-Wen, W.; Jie, Z. Introduction of CMIP5 experiments carried out with the climate system models of Beijing Climate Center. Adv. Clim. Chang. Res. 2013, 4, 41-49. [CrossRef]

51. Gent, P.R.; Danabasoglu, G.; Donner, L.J.; Holland, M.M.; Hunke, E.C.; Jayne, S.R.; Lawrence, D.M.; Neale, R.B.; Rasch, P.J.; Vertenstein, M.; et al. The community climate system model version 4. J. Clim. 2011, 24, 4973-4991. [CrossRef]

52. Voldoire, A.; Sanchez-Gomez, E.; Salas y Mélia, D.; Decharme, B.; Cassou, C.; Sénési, S.; Valcke, S.; Beau, I.; Alias, A.; Chevallier, M.; et al. The CNRMCM5.1 global climate model: Description and basic evaluation. Clim. Dyn. 2013, 40, 2091-2121. [CrossRef]

53. Donner, L.J.; Wyman, B.L.; Hemler, R.S.; Horowitz, L.W.; Ming, Y.; Zhao, M.; Golaz, J.-C.; Ginoux, P.; Lin, S.-J.; Schwarzkopf, M.D.; et al. The dynamical core, physical parameterizations, and basic simulation characteristics of the atmospheric component AM3 of the GFDL global coupled model CM3. J. Clim. 2011, 24, 3484-3519. [CrossRef]

54. Jones, C.D.; Hughes, J.K.; Bellouin, N.; Hardiman, S.C.; Jones, G.S.; Knight, J.; Liddicoat, S.; O'Connor, F.M.; Andres, R.J.; Bell, C.; et al. The HADGEM2-AS implementation of CMIP5 centennial simulations. Geosci. Model Dev. 2011, 4, 543-570. [CrossRef]

55. Dufresne, J.-L.; Foujols, M.-A.; Denvil, S.; Caubel, A.; Marti, O.; Aumont, O.; Balkanski, Y.; Bekki, S.; Bellenger, H.; Benshila, R.; et al. Climate change projections using the IPSL-CM5A earth system model: From CMIP3 to CMIP5. Clim. Dyn. 2013, 40, 2123-2165. [CrossRef]

56. Watanabe, M.; Suzuki, T.; O'ishi, R.; Komuro, Y.; Watanabe, S.; Emori, S.; Takemura, T.; Chikira, M.; Ogura, T.; Sekiguchi, M.; et al. Improved climate simulation by MIROC5: Mean states, variability, and climate sensitivity. J. Clim. 2010, 23, 6312-6335. [CrossRef]

57. Bentsen, M.; Bethke, I.; Debernard, J.B.; Iversen, T.; Kirkevåg, A.; Seland, Ø.; Drange, H.; Roelandt, C.; Seierstad, I.A.; Hoose, C.; et al. The Norwegian earth system model, NORESM1-M-Part 1: Description and basic evaluation of the physical climate. Geosci. Model Dev. 2013, 6, 687-720. [CrossRef]

58. Santos, M.; Fragoso, M. Precipitation variability in northern Portugal: Data homogeneity assessment and trends in extreme precipitation indices. Atmos. Res. 2013, 131, 34-45. [CrossRef]

59. Tramblay, Y.; El Adlouni, S.; Servat, E. Trends and variability in extreme precipitation indices over Maghreb countries. Nat. Hazards Earth Syst. Sci. 2013, 13, 3235-3248. [CrossRef]

60. Bronaugh, D. Package 'climdex.pcic'. 2014. Available online: https://cran.r-project.org/web/packages / climdex.pcic/climdex.pcic.pdf (accessed on 17 February 2016).

61. McKee, T.; Doesken, N.; Kleist, J. The relationship of drought frequency and duration to time scales. In Proceedings of the 8th Conference on Applied Climatology, Anaheim, CA, USA, January 17-22 1993.

62. Chen, T.; Werf, G.R.; Jeu, R.A.M.; Wang, G.; Dolman, A.J. A global analysis of the impact of drought on net primary productivity. Hydrol. Earth Syst. Sci. 2013, 17, 3885-3894. [CrossRef]

63. Wang, Q.; Wu, J.; Lei, T.; He, B.; Wu, Z.; Liu, M.; Mo, X.; Geng, G.; Li, X.; Zhou, H.; et al. Temporal-spatial characteristics of severe drought events and their impact on agriculture on a global scale. Quat. Int. 2014, 349, 10-21. [CrossRef]

64. Neves, J. Package 'spi'. Available online: https://cran.r-project.org/web/packages/spi/spi.pdf (accessed on 5 April 2016).

65. Kendall, S. Time Series; Oxford University Press: New York, NY, USA, 1976.

66. Xu, W.; Zou, Y.; Zhang, G.; Linderman, M. A comparison among spatial interpolation techniques for daily rainfall data in Sichuan Province, China. Int. J. Climatol. 2015, 35, 2898-2907. [CrossRef]

67. Taylor, K.E. Summarizing multiple aspects of model performance in a single diagram. J. Geophys. Res. Atmos. 2001, 106, 7183-7192. [CrossRef] 
68. Taye, M.T.; Ntegeka, V.; Ogiramoi, N.P.; Willems, P. Assesment of climate change impact on hydrological extremes in two source regions of the Nile River Basin. Hydrol. Earth Syst. Sci. 2011, 15, 209-222. [CrossRef]

69. Schoof, J.T. High-resolution projections of 21st century daily precipitation for the contiguous U.S. J. Geophys. Res. Atmos. 2015, 120, 3029-3042. [CrossRef]

70. Mishra, V.; Lettenmaier, D.P. Climatic trends in major U.S. urban areas, 1950-2009. Geophys. Res. Lett. 2011, 38, 136. [CrossRef]

71. Zilli, M.T.; Carvalho, L.M.V.; Liebmann, B.; Silva Dias, M.A. A comprehensive analysis of trends in extreme precipitation over southeastern coast of Brazil. Int. J. Climatol. 2016. [CrossRef]

72. Lovejoy, S. What is climate? Eos Trans. Am. Geophys. Union 2013, 94, 1-2. [CrossRef]

(C) 2017 by the authors; licensee MDPI, Basel, Switzerland. This article is an open access article distributed under the terms and conditions of the Creative Commons Attribution (CC BY) license (http:/ / creativecommons.org/licenses/by/4.0/). 